\title{
堵感紙に就ての二三の知見
}

大日本慗料株式会社茅ヶ䗁工場

工場長大谷 信”吉

\section{A Few Opinions on Intensifying Screen}

Factory Superintendent. Chigasaki Kojo. Dainippon Toryo $\mathrm{K}_{\mathrm{K}} \mathrm{K}$

諈和が成立して海外との物资の交流が常態に復して みると種々の工業生産品に於て海外品に劣る点が明瞙

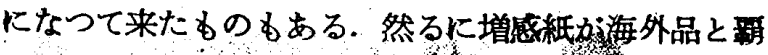

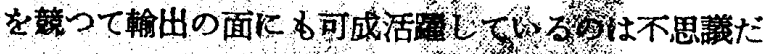

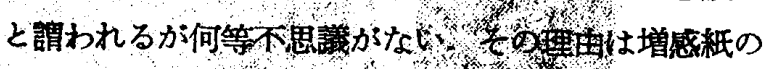

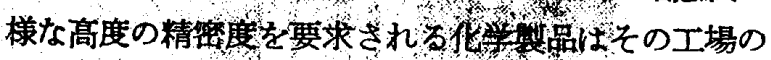

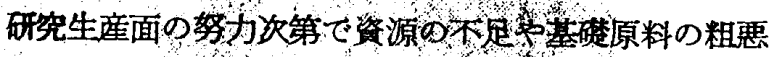
さをカハーして位秀な製品を生库出莱るからである。

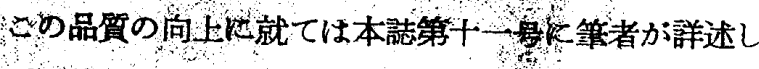
तथ了.

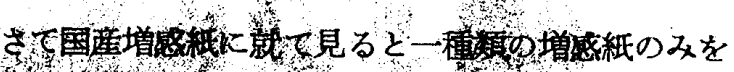

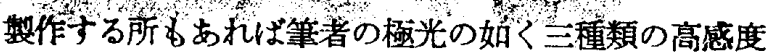
型 (HS) 万能型 (MS) 及びディテール型 (FS)を生 座する所すある。これる海外品と比較する場合本誌第 十一号にも書いている様に海外品には極光 (HS) の様 な高感度のすのはないのであつて, (HS) は我国の如

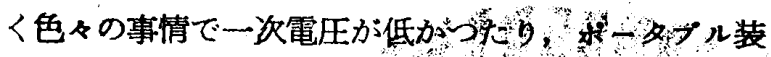

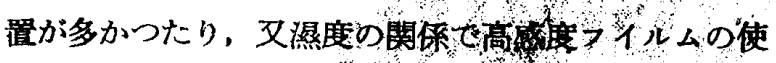

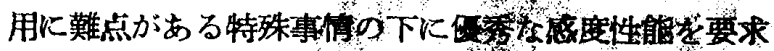

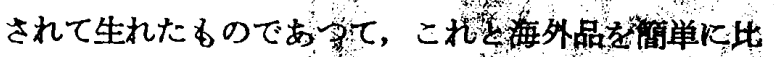

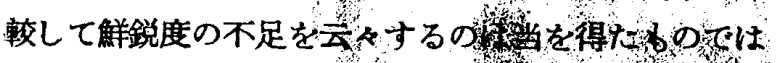

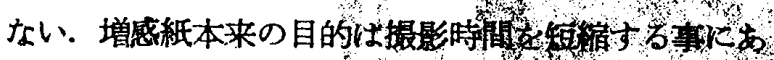
るので,この見地からして等しい堌能力即ら同じ

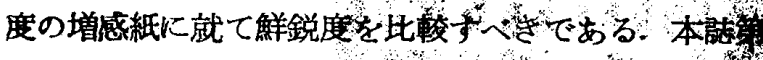

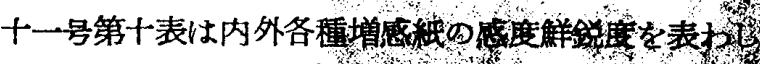

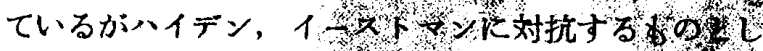

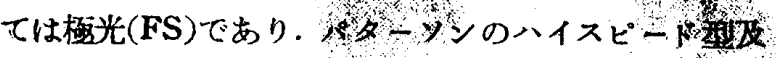

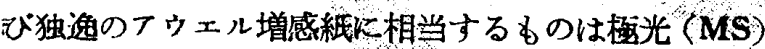
である. イーストマンと極灰(HS)を比較して国産の 鮮鋭度劣机りとして品質を云タするのは的をはずした

係でつて当然 (FS) が比較さるべきだと考える.

次に最近筆者の梅光レントゲン研究所に於て実験結 果から増感指数と仮称した増感紙の感度性能を表示す る数值を得たので概胳を説明し本表示法による内外製 品の数値を記載する.

徉来一般に使用された増感率はフイルムの状態, 現

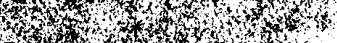

4 13.

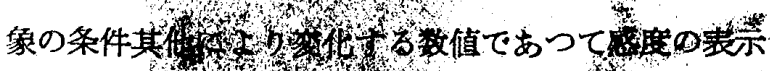

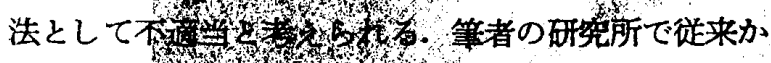

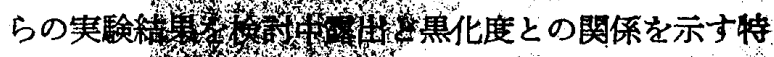
性曲楾が各

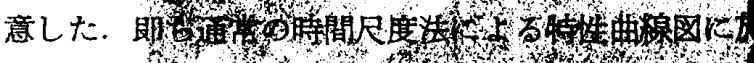

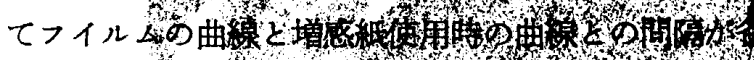

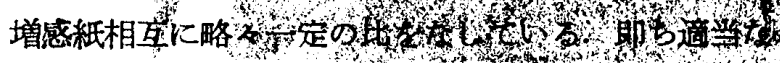
槽準堌感紙のその問障を単位にとれば任空の堌感紙の それは一定の数值として得られる.

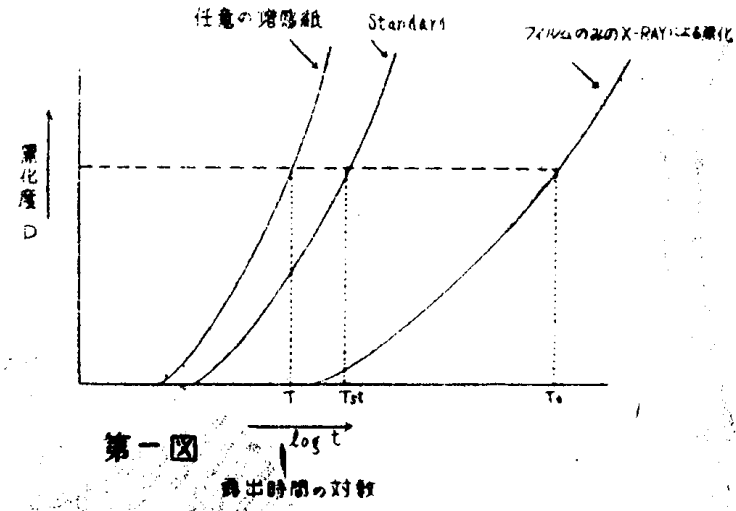

即ち第一因より

Log ToHog $T=\operatorname{m}$ (Log To-Log Tst

$$
\begin{aligned}
& \text { 申-常数 } \\
& \log \frac{T o}{T} \log _{\frac{T o}{T s t}}
\end{aligned}
$$

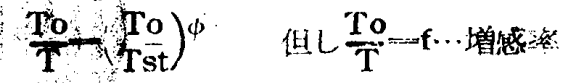

$$
\begin{aligned}
& \frac{\log f}{\log f s t} \phi \quad \therefore f=f s t \\
& \text { p……増感指数……常数 }
\end{aligned}
$$

即ちこの 中なる増感指数を最近の内外革各楎増感紙 につき算出した結果及び鲜鋭度指数を記載して御参考 に供し度いと思5.（第一表参炤）

最後に筆者が各地の技師会其他の御集会等に御何い した時に良く受ける御注意や御質問の点の二三就て 記して兒よ 5 .

増感紙の表百自の保護膜が縁のちがらメクレルと云う 御注意は四，五年前の製品に就て良く受けけたのてある 
第一表 各種増感紙の性能比較

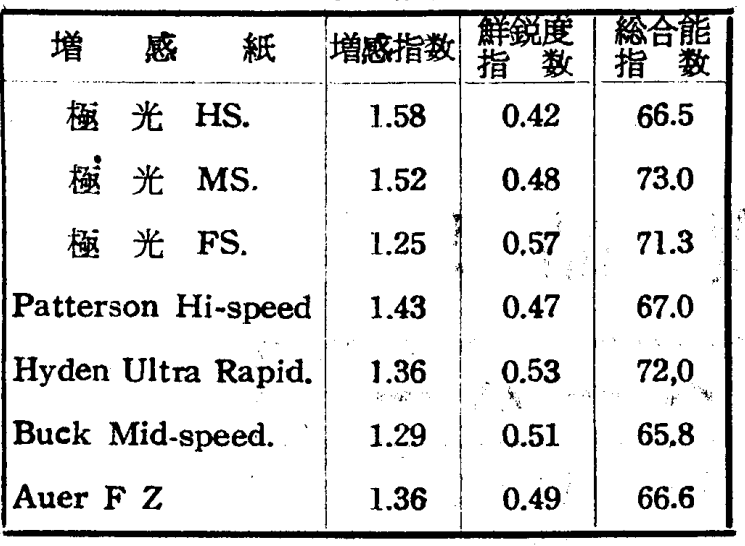

が，その後の改良でこの久点は無くなつたが保櫵膜が フクレ上つたと云う事を聞く，勿論觯鋭度を上げる為 製作上智光物貿の結合剂を少なくする等のために強度 の機械的揁性に耐える様作ることは困難であるが通 常の場合これは濕度の髟響であつて,この注意を受け

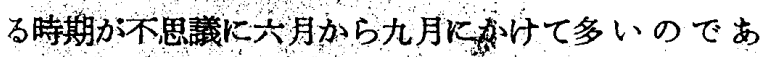

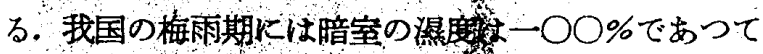
何等加の事情により保護膜表面か致点に達寸ると眼に

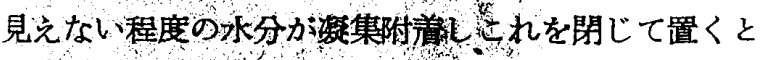
丁度ガラスに水分をつけて二枚重ねた様になかなか取 れなくなつて来る，これは表面か平滑で密着の良い増 感紙洼ど開き難くなり無理に開くと保護膜の一部が持 ち上るのである. 濕度の高い日に増感紙をカセッテに 誫り付ける場合す良く注意願い度いのである。

次は増感紙の表面に灰色及至褐色の活点が発生する 場合である. 如何にも内部から出た污点の様でメーカ 一の責任を間われる場合が多いのであるか，実はそれ が現像液とか現像薬品（特汇現像主蒋）の污点であ る. 前者は液の飛散したとか不注意にフイルムの水切
りをやつた場合に起るが後者はとの計量文は投入の蝪

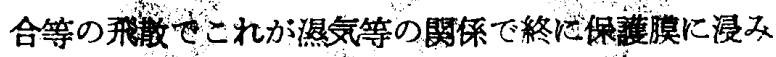
付いて起るのである.

第三に間題になるのが部分的なボヶの間題である。 良く中心部がボヶルから取り换えてくれとの話がある のであるが，これが大体四切文は大陸版等の大版物に 限られている.八切やキャビ衵では今日まで聞いた 事がない：この原因が二つつつてカセッテを見せて頂 いてフロント僛を下にし水平な机の上に置くと廻転す る場合がある. カセッテのバネ初強すぎたり, ベーク ライトが弱場合ベークライトの中央部がフクレて密

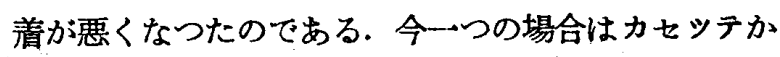
ら增感紙を取つて見ると前に使用した増感紙の破片が フチの方に残つていてモり上つている場合がある。こ の場合は中央部に空閒が出来て密着は当然低下するか けである. 前述の増感紙の比較試験等の場合るこの点 特に充分な検討を加えて頂き底い，従来カセッテの良 否にくらぺて增感紙の良否が非常に強く叫ばれた際に 我々メーカーに一種のヒガミがあつたのであるが最近 はカセッテに就ての選択が相当強くなつて来た点增感 紙メーカーとして大変有難い事に考えている.

戦前に比較して結核対策の重要性が強く認識され増 感紙の使用回数も㦥期的に増大した今日ではやはり增 感紙の損傷率も高まつて来るので诵品ではない消耗品 だとの気持で早目の取り換えに啃つて診断を容易にさ れる事を乱願いする（実際フメリカでは数ヶ月で取り 替えをすると云らことる聞いている) と同時に高価な 海外品の替りに内地品を使用して頂ぎ，その差類でカ セッテの交換も願えればレントダン診断に対する御苦 心す一段と容易さを増すのでないかと考劣ている次第 である.

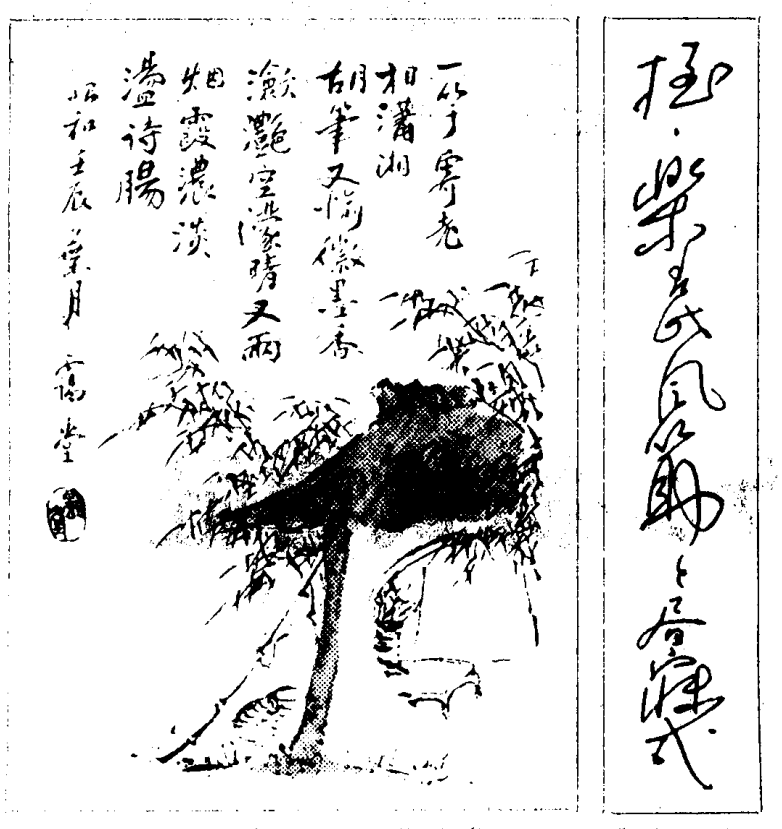

東京㹂科器械同業組合名譽顧問

日本 醫科學會評議員

\section{岩本藤吉釟近詠}

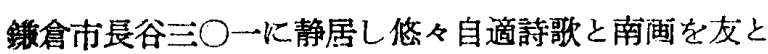

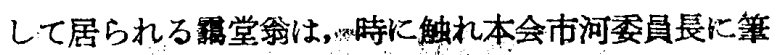
のすさびをよせられる。左の非句は盛賈七月廿八日 附, 詩と画は八月十七日附, 悀の面目躍如として現は れている. 